\title{
Klasyfikacja teorii prawa naturalnego oraz jego wpływ na świadomość społeczeństwa
}

\begin{abstract}
SUMMARY
Classification of the theories of natural law and its impact on public awareness

As the Author of this article demonstrates, natural law is the subject of research by many different sciences, especially by the philosophy of law. Natural law affects public awareness. Classification of the theories of natural law is based on the sources of this law, including the theory of variation and immutability of natural law. Grotius developed the concept of natural law and with it laid the foundations for international law. Not all saw this as being for the good, voicing opinion that natural law was of an immoral character.

Key words: natural law, public awareness, justice, society, human being, philosophy of law.

Słowa kluczowe: prawo naturalne, świadomość, sprawiedliwość, społeczeństwo, człowiek, filozofia prawa.

Nigdy los nie wydawał się człowiekowi zadowalający. To wyjaśnia bunty krwawe i bezkrwawe w ciągu dziejów, mające na celu zniwelować sprzeczność między doświadczanym uciskiem a poczuciem sprawiedliwości.

Sokrates stał się symbolem kogoś, kto bezwzględnie przestrzega ustanowionego prawa. Ale po doświadczeniach, które przyniosła II wojna światowa, po zbrodniach dokonywanych niejednokrotnie zgodnie z prawem, taka postawa przestaje stanowić wzór do naśladowania. Uznanie istnienia prawa ponadustawowego zezwala na legalny bunt, jeśli rządzący naruszają wolność i sprawiedliwość. Nie jest się skazanym na samowolne decyzje tych, którzy mają władzę.

Sprawiedliwość od początków ludzkich dziejów pobudzała umysły i wzniecała uczucia. W starożytnej Grecji zrodziły się dwa przeciwstawne nurty, które obecnie również mają swoich zwolenników. W myśl jednego z nich nie ma sprawiedliwości innej niż wyrażona w prawie stanowionym, czyli pozytywnym. Według drugiego nurtu, sprawiedliwość ponadustawowa jest doskonalsza od sprawiedliwości zawartej w prawie stanowionym przez człowieka.
\end{abstract}


Sprawiedliwość ponadustawowa bywa określana mianem praw człowieka, podstawowych wartości, poczuciem słuszności, wytycznymi dla życia w społeczeństwie, prawem pierwiastkowym, transpozytywnym, prawem natury, inaczej prawem naturalnym. Jest to sprawiedliwość niezależna w swej treści od wyników głosowania bądź innych decyzji podejmowanych w drodze negocjacji.

W literaturze naukowej wskazywane bywają następujące źródła prawa natury: istota człowieka, Bóg, rozum, godność człowieka. Na ogół w polskiej powojennej literaturze naukowej dyskusje dotyczą tych teorii, które jako ostateczne źródło tego prawa uznają Boga. Spowodowało to u nas błędne mniemanie o koniecznym związku wszelkich teorii prawa natury z wiarą religijną. Niezależnie od dyskusji na temat źródła tego prawa, stanowi ono uzasadnienie dla działań w obronie wolności, sprawiedliwości, czy równości, czyli w obronie najwyższych wartości człowieka. Jest to prawo, które występuje wyłącznie w ludzkim świecie i nie ma nic wspólnego z prawami przyrody, które dotyczą całego świata przyrody, a w tym także człowieka.

W dziejach ludzkości zachodzi ścieranie się poglądów prawnonaturalnych, a więc głoszących istnienie ponadustawowej sprawiedliwości ze stanowiskiem prawopozytywistycznym. W myśl tego ostatniego nie ma innego prawa niż ustanowione przez władzę państwową. Prawo pozytywne jest jedyną miarą sprawiedliwości według tej szkoły. Pozytywiści prawni przyjęli, że porządek w państwie jest zbudowany wyłącznie przez człowieka, a wszelkie prawo opiera się na ustawie. Prawdopodobnie jedni będą skłonni do przyjęcia prawa natury, podczas gdy inni będą głosić, że ono nie istnieje.

Wstrząsy, które przyniosła I i II wojna światowa doprowadziły do odrodzenia dociekań nad sprawiedliwością ponadustawową, inaczej prawem natury. Trzeba pamiętać, że teorie tego prawa mogą także umacniać władzę tyranów. Na przykład w okresie hitleryzmu tworzono w Niemczech teorie prawa natury. Pojmowane było jako prawo wspólnoty germańskiej. Wybitnym teoretykiem narodowo- socjalistycznego prawa natury był H. H. Dietze.

Zbrodnie ostatniej wojny światowej skłoniły do poszukiwania na nowo kryteriów pozwalających na odróżnienie prawa od - mającego tylko jego formę zewnętrzną - bezprawia. Skłoniły ku poszukiwaniom wartości, które prawo powinno urzeczywistniać, jeśli ma być godne tego miana.

Prawo natury począwszy od starożytności aż do 1896 r. było pojmowane jako prawo niezmienne. W starożytności wskazywano istotę człowieka jako jego źródło, w średniowieczu natomiast, pod wpływem chrześcijaństwa, uznano prawo wieczne, inaczej Boga, jako źródło tej ponadustawowej sprawiedliwości.

Arystoteles zespolił prawo natury z moralnością określając następująco podstawową zasadę tego prawa: dobro należy czynić, zła należy unikać. W czasach odrodzenia Grocjusz, widząc Europę rozdartą wojnami religijnymi i zarazem przeciwstawnymi poglądami moralnymi, doszedł do wniosku, że ludzkość może połączyć jedynie prawo nieodwołujące się do moralności. Jego zdaniem 
podstawowa zasada prawa natury sprowadza się do nakazu przestrzegania umów i wynagradzania krzywd. Prawo natury głosi też, by przestępców karać.

Tę koncepcję prawa natury pojmowanego jako immoralne rozwinęli w czasach nowożytnych przede wszystkim Locke, Hobbes i Kant. Zespolili oni podstawową zasadę prawa natury z wolnością. Jej prawnonaturalny charakter sprawia, że jest niezbywalna. Locke i jego kontynuatorzy wywodzą z prawa natury - prawo obywateli do oporu wobec władzy państwowej jeżeli narusza ona wolność jednostek. Współcześnie określa się je prawem do nieposłuszeństwa obywatelskiego.

Istnienia prawa naturalnego nie da się udowodnić w sposób wykluczający stanowisko przeciwne. Zaznaczają się trzy następujące poglądy: (1) negujący istnienie tego prawa, (2) głoszący jego obiektywne istnienie oraz (3) pogląd, w myśl którego prawo to funkcjonuje jedynie w ludzkiej świadomości.

U podstaw koncepcji prawnonaturalnych zwiera się filozofia człowieka. Pogląd, że każdemu człowiekowi jest niezbędny jednakowy zakres wolności. Wspólne jest również uznanie, że poczucie sensu życia staje się spełnione, gdy człowiek oddaje się czemuś, co przekracza wymiar codziennego doświadczenia. Teorie prawa natury, zwłaszcza formułowane od 1896 r. - o czym będzie mowa dalej - przyczyniają się do zrozumienia, że zadaniem człowieka jest podejmowanie działań wyprowadzających go poza obszar egoizmu rodzinnego; działań ukierunkowanych przez ideały. Dążenie do ich realizacji łączy jednostkę z ludzkością.

Ogólny charakter prawa natury, inaczej naturalnego, sprawia, że można powołując się na nie, uzasadniać nieraz sprzeczne poglądy jako prawnonaturalne. Na przykład przyjmuje się pogląd mający źródło w tradycji arystotelesowsko-tomistycznej, że z tego prawa wynika własność prywatna. Jednocześnie przemilcza się u nas obecnie pogląd wielu chrześcijańskich filozofów, w tym Mouniera - twórcy personalizmu chrześcijańskiego - że własność prywatna jest źródłem niesprawiedliwości i zła w życiu społeczeństwa. Część neotomistów wprowadziła korektę do poglądu Tomasza z Akwinu i twierdzi, że z prawa natury wynika prawo każdego do korzystania z własności. Forma własności prywatna, państwowa, spółdzielcza - ma być określana przez prawo pozytywne uwzględniające dobro wspólne.

Prawo natury dotyczy wyłącznie człowieka i jest czymś odmiennym od praw świata przyrody oraz od prawa pozytywnego.

Bezwzględne przestrzeganie prawa pozytywnego staje pod znakiem zapytania w szczególnych okolicznościach. Są nimi przewroty w państwie, niekoniecznie związane z przelewem krwi. Problem praworządności stał się niezmiernie aktualny, skoro ma się np. niejednokrotnie pretensje do tych, którzy orzekali zgodnie z przepisami prawnymi minionego okresu w Polsce. Zadaniem adwokata, sędziego, prokuratora nie jest ocenianie prawa stanowionego, 
lecz stosowanie go. Natomiast ustawodawcy zobowiązani są do ocen i zmian w przepisach prawnych, ażeby pełniej odpowiadały poczuciu sprawiedliwości.

W Polsce po II wojnie światowej, a ściślej od 1950 r., uznano teorię prawa naturalnego za „przejaw burżuazyjnego sposobu myślenia” i nie odwoływano się do niego w życiu publicznym. Teoria tego prawa była u nas rozwijana głównie w Akademii Teologii Katolickiej (dziś Uniwersytet Stefana Kardynała Wyszyńskiego), uczelni państwowej powstałej w 1954 r. oraz w KUL uczelni prywatnej. Mimo administracyjnej likwidacji katedr filozofii prawa, zachowała się ona w KUL. Miejsce katedr filozofii prawa zajęły katedry teorii państwa i prawa, które interpretowały prawo w duchu marksizmu, negując istnienie prawa natury.

Nikt się nie spodziewał, że nagle po 1989 r. nastąpi w Polsce okres odrodzenia tych teorii. Nikt też nie mógł był przypuszczać, że wielu spośród uczonych krytykujących teorię prawa naturalnego - zacznie pisać książki odwołujące się do tego prawa. Stanowiska wcześniejszego z reguły nie odwoływano. Dominuje w Polsce tomistyczne ujęcie tego prawa. Nie ma jak dotąd przypadków powoływania się przez polityków i publicystów na teorie prawa naturalnego odległe od interpretacji arystotelesowsko-tomistycznej.

Prawo natury stanowi przedmiot zainteresowania specjalistów wielu dziedzin: filozofii prawa, etyków, teologów, jak również filozofów polityki. Pojęcie prawa natury zmieniało się w kolejnych okresach dziejów, ale także nabierało odmiennego znaczenia $\mathrm{w}$ rozmaitych teoriach formułowanych $\mathrm{w}$ tym samym czasie i w takich samych okolicznościach społecznych, ekonomicznych i kulturowych. Jednakże w polskiej powojennej literaturze naukowej dochodzi często do głosu pogląd o ścisłej zależności między warunkami społeczno-gospodarczymi a teoriami prawa natury. Na przykład wyodrębniane bywają teorie prawa natury okresu niewolnictwa, feudalizmu, kapitalizmu oraz epoki współczesnej. Na gruncie poglądów chrześcijańskich filozofów funkcjonuje klasyfikacja teorii prawa naturalnego na kosmiczno-teologiczną w starożytności, psychologiczno-teologiczną teorię św. Augustyna, bytowo analogiczną św. Tomasza z Akwinu oraz epistemologiczno-iedalistyczną teorię szkoły prawa natury XVII i XVIII w.

Z neokantyzmu wywodzi się rozróżnienie obowiązującego, nawet nieodpowiedniego prawa, pozostającego jednak prawem oraz prawa natury pojmowanego jako miara prawa tu i teraz ustanowionego. Projekty ustaw zawierających słuszne prawo - czyli doskonalsze niż aktualnie obwiązujące - mają być kierunkowskazem dla działań ustawodawczych. Prawo de lege ferenda, czyli prawo jakim ono być powinno, odbiega nieraz znacznie od obowiązującego ustawodawstwa. Niezmienna forma jaką jest powinność, nie pozostaje w sprzeczności z tym, że konkretne rozwiązania są ważne tylko dla określonego państwa w określonym czasie.

Klasyczne teorie prawa natury wskazują na istotę człowieka jako źródło tego prawa oraz podkreślają jego niezmienny charakter sprowadzający się do 
podstawowej normy moralnej. Prawo to istnieje nie tylko w sensie gnoseologicznym, ale także ontologicznym.

Pojmowanie prawa natury uległo począwszy od 1896 r. daleko idącym przemianom. Stało się to za sprawą Rudolfa Stammlera, kantysty oraz Leona Petrażyckiego, twórcy szkoły psychologicznej. Niezależnie od siebie sformułowali w tym samym czasie teorię prawa natury o zmiennej treści odbiegającej od klasycznej teorii tego prawa. Za sprawą wyżej wymienionych uczonych przestano wiązać prawo natury z istotą człowieka, przestano je traktować jako niezmienne oraz przestano widzieć w nim normę postępowania.

Prawo natury ma określać stan jaki być powinien, stając się wytyczną dla działań prawodawczych. Prawo natury o zmiennej treści obowiązuje jedynie prawodawców, a nie całe społeczeństwo.

Prawo to staje się kryterium oceny prawa obowiązującego, bowiem ujmowane jest jako propozycja przyszłego, słusznego prawa dla danego czasu i miejsca. Nie podwaja ono porządku prawnego, ponieważ nie jest czymś gotowym lecz tym, co ma zostać urzeczywistnione. Tak pojęte prawo natury jest tworem rozumu człowieka żyjącego w określonym czasie. Niezmiennej formie tego prawa, którą jest powinność, towarzyszy zmieniająca się treść.

Dociekania nad prawem natury stanowią charakterystyczną cechę dotychczasowych okresów kultury, począwszy od starożytnej Grecji. Zdarzało się, że dominowały nurty odrzucające teorie prawa natury. Do nich należał przede wszystkim pozytywizm prawny, szkoła analityczna, szkoła historyczna, oraz marksizm. Ale nie przesądziły one o zaniknięciu prądów prawnonaturalnych, które odżyły po ostatniej wojnie światowej. Dziś częściej występuje odwoływanie się do tego prawa pod nazwą prawa człowieka. Mają to być prawa, które dotyczą wyłącznie człowieka. Nikt nie może być ich pozbawiony.

Teorie dynamiczne powstały najpóźniej, bo w okresie II wojny światowej. Pierwszym ośrodkiem tych teorii były Stany Zjednoczone. Teorie dynamiczne nie były jednak dziełem amerykańskich filozofów prawa, ale tych, którzy w ostatnich latach międzywojennych oraz w latach II wojny światowej znaleźli w USA schronienie. W rezultacie bolesnych doświadczeń zwrócili się ku prawu natury, by w nim znaleźć przeciwwagę dla zbrodni państw totalitarnych. Dynamiczne teorie prawa natury wiążą genezę tego prawa z istotą, bądź godnością człowieka. Treść tak pojętego prawa natury ma charakter rozwojowy. Jest ona zmienna i zarazem niezmienna, co wyjaśnia przykład reguł logiczno-matematycznych, które są niezmienne, aczkolwiek stosowane w rozmaitych dziedzinach.

Tendencja, by z obszaru wiedzy naukowej zniknęły teorie prawa natury prowadzi do tego, że zaczyna ono być identyfikowane z dowolnymi nakazami tego, kto sprawuje władzę. Odwoływanie się do sprawiedliwości ponadustawowej nie ustanie dopóki w państwie będą przejawy niesprawiediwości. Ona prowadzi do poczucia innej sprawiedliwości niż pozytywnoprawna. Rozwiązaniem 
dylematu może być pogląd, by nie kwestionować obowiązującego prawa, ale przekształcać je w kierunku ideału sprawiedliwości. Prawo powinno znajdywać uzasadnienie $\mathrm{w}$ wyższych wartościach, a nie w interesach grup je tworzących.

Współcześnie demokracja jest ustrojem zalecanym, ale zachodzą w takim państwie częste zmiany grup rządzących. Zdarza się, że co cztery lata inna partia polityczna obejmuje ster rządów. W związku z tym, część przepisów prawnych podlega zmianie. W takiej atmosferze chaosu politycznego i prawnego istotne znaczenie ma oddziaływanie drogowskazu bardziej trwałego niż zmieniające się prawo. Pełnić jego rolę może przede wszystkim teoria prawa natury o zmiennej treści. Wyznacza ona bowiem kierunek stanowienia prawa.

W państwach totalitarnych miejsce dominacji prawa zajmuje ideologia. Takim mianem należy określać państwa, które zezwalają jedynie na monizm światopoglądowy. Pluralizm światopoglądowy charakteryzuje natomiast współczesny sposób pojmowania demokracji. Neutralność światopoglądowa państwa staje się warunkiem rzeczywistej wolności obywateli. Demokracja nie powinna być utożsamiana z żadną spośród koncepcji politycznych, ani z żadnym spośród światopoglądów. Wszystkie poglądy należy traktować jako równowartościowe. Wiąże się to zarazem z przyznaniem wolności wszelkim mniejszościom, w tym także światopoglądowym i religijnym.

Tradycyjne teorie prawa natury, pojmujące dobro jako wartość absolutną, narzucają społeczeństwu prawo podporządkowane jednej spośród wielu teorii etycznych. W konsekwencji następuje ograniczenie wolności. Podlegają temu np. mniejszościowe Kościoły i Związki Wyznaniowe głoszące, stosownie do swoich wyznan, teorie etyczne.

Odrodzenie teorii prawa natury nastąpiło po II wojnie światowej. Oddziałało również w wymiarze praktycznym na Europę. Mianowicie Proces Norymberski opierał się na prawie naturalnym, podobnie jak wcześniej Wielka Rewolucja Francuska 1789 r.

\section{Bibliografia}

Szyszkowska M., Europejska filozofia prawa, Warszawa 1995.

Szyszkowska M., Teorie prawa natury XX wieku w Polsce, Warszawa 1982.

Szyszkowska M., Zarys filozofii prawa, Białystok 2000. 